Abstract: Divalent metal complexes of ligand 2-methoxybenzylidenepyruvate with $\mathrm{Fe}, \mathrm{Co}, \mathrm{Ni}$, $\mathrm{Cu}$ and $\mathrm{Zn}$ as well as sodium salt were synthesized and investigated in the solid state. TG curves of these compounds were obtained with masses sample of 1 and $5 \mathrm{mg}$ under nitrogen atmosphere. Different heating rates were used to characterize and study these compounds from the kinetic point of view. The activation energy and pre-exponential factor were obtained applying the Wall-Flynn-Ozawa method to the TG curves. The obtained data were evaluated and the values of activation energ $(\alpha)$. The results show that due to mass sample, different activation energies were obtained. The results are discussed mainly taking into account the linear dependence between the activation energy and the pre exponential factor, where was verified the effect of kinetic compensation (KCE) and possible linear relations between the dehydrations steps of these compounds.

Keywords: bivalent metal ions, 2-methoxybenzylidenepyruvate, non-isothermal kinetics, dehydration

\section{References}

[1] Reimer, M. and Howard. M. J. Am. Chem. Soc. 50 (1928) 2506

[2] Kobelnik, M.; Schnitzler, E.; Ionashiro, M. J. Therm. Anal. Cal. 91 (2008) 891.

[3] Fernandes, N. S.; Carvalho Filho, M. A. S.; Mélios, C. B.; Ionashiro, M. J. Therm. Anal. Cal. 59 (2000) 663.

[4] Fernandes, N. S.; Carvalho Filho, M. A. S.; Mélios, C. B.; Ionashiro, M. J. Therm. Anal. Cal 73 (2003) 307.

[5] N. S. Fernandes, S. A. Araujo, M. Ionashiro, Ecl. Quím. 31(2) (2006) 39

[6] Fernandes, N. S.; Carvalho Filho, M. A. S.; Mendes, R. A.; Mélios, C. B.; Ionashiro, M. J. Therm. Anal. Cal. 76 (2004) 193.

[7] A. B. Siqueira, C. T. de Carvalho, E. C. Rodrigues, E. Y. Ionashiro, G. Bannach, M. Ionashiro, Ecl. Quím 32(4) (2007) 49-54.

[8] Ionashiro, E. Y.; Fertonani, F. L.; Mélios, C. B.; Ionashiro, M. J. Therm. Anal. Cal. 79 (2005) 299.

[9] Bannach, G.; Schnitzler, E.; Mélios, C. B.; Ionashiro, M. Ecl. Quim. 29 (2004) 31

[10] Souza JL, Kobelnik M, Ribeiro CA, Capela JMV. Kinetics study of crystallization of PHB in presence of hydrociacids. J. Therm. Anal. Cal. 97 (2009) 525.

[11] Flynn, J. H.; Wall, J. Nat. Bur. Stand. 70A (1966) 487.

[12] Ozawa, T. Bull. Chem. Soc. Jpn. 38 (1965) 1881

[13] Ozawa, T. J. Therm. Anal. 2 (1970) 30

[14] Chen, D.; Gao, X.; Dollimore, D. A. Thermochim. Acta 215 (1993) 109.

[15] Málek, J. Criado, J. M., Sestak, J., Militky, J. Thermochim. Acta 153 (1989) 429

[16] Vyazovkin, S.; Wight, C. A. Int. Rev. Phys. Chem. 17

[17] Flynn, J.H.; Wall, L. A. J. Polymer Sci., Pt. B., 4 (1966)

[18] C.D. Doyle, J. Appl. Polymer Sci. 5 (1961) 285.
[19] Kobelnik, M.; Bernabé, G. A.; Ribeiro, C. A.; Capela, J. M. V.; Fertonani, F. L. J. Therm. Anal. Calorim. 97 (2009)

[20] Galwey A. K.; Brown M. E. Thermal Decompositions of onic Solids. $1^{\text {th }}$ ed. Amsterdan: Elsevier; 1999.

[21] Galwey A. K. Thermochim. Acta. 2004,413,139.

22] Prasad, T. P.; Kanungo, S. B.; Ray, H. S. Thermochim cta. 2002,203,503.

[23] N. Koga, J. Sestak. J. Therm. Anal. 37 (1991) 1103.

[24] N. Koga. Thermochim. Acta 244 (1994) 1.

[26] J. G. R. Poço; H., Furlan; R., Giudici. Journal Physical Chemical B 106 (2002) 4873.

\title{
MATHEMATICAL EQUATION CORRECTION TO SPECTRAL AND TRANSPORT INTERFERENCES \\ IN HIGH-RESOLUTION CONTINUUM SOURCE \\ FLAME ATOMIC ABSORPTION SPECTROMETRY: DETERMINATION OF LEAD IN PHOSPHORIC ACID
}

Jorge Luiz Raposo Jra , Silvana Ruella de Oliveira ${ }^{a}$, Joaquim Araújo Nóbrega ${ }^{b}$, José Anchieta Gomes Neto ${ }^{a^{*}}$

\author{
São Paulo State University - Unesp, Analytical Chemistry Department \\ P.O. Box 355, 14801-970 Araraquara - SP, Brazil \\ *anchieta@iq.unesp.br

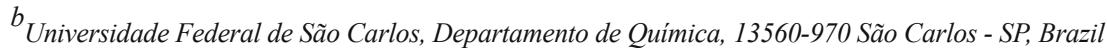

Abstract: In this work, a new mathematical equation correction approach for overcoming spectral and transport interferences was proposed. The proposal was applied to eliminate spectral interference caused by $\mathrm{PO}$ molecules at the $217.0005 \mathrm{~nm} \mathrm{~Pb}$ line, and the transport interference caused by variations in phosphoric acid concentrations. Correction may be necessary at $217.0005 \mathrm{~nm}$ to account for the contribution of PO, since A $217.0005 \mathrm{~nm}=\mathrm{A}_{2}^{217.0005 \mathrm{~nm}}+\mathrm{A}$ $217.0005 \mathrm{~nm}$. This may be easily done by measuring other PO wavelengths (e.g. $217.0458 \mathrm{~nm}$ ) and calculating the relative contribution of $\mathrm{PO}$ absorbance $\left(\mathrm{A}_{\mathrm{O}}\right)$ to the total absorbance $\left(\mathrm{A}_{\text {total }}\right)$ and calculating the relative contribution of $\mathrm{PO}$ absorbance $\left(\mathrm{A}_{\mathrm{PO}}\right)$ to the total absorbance $\left(\mathrm{A}_{\text {total }}\right)$
at $217.0005 \mathrm{~nm}: \mathrm{A}_{\mathrm{pb}}^{217.0005 \mathrm{~nm}}=\mathrm{A}_{217.0005 \mathrm{~nm}}-\mathrm{A}_{\mathrm{pO}}^{217.0005 \mathrm{~nm}}=\mathrm{A}_{\text {total }}{ }_{217.0005 \mathrm{~nm}}-\mathrm{k}\left(\mathrm{A}_{\mathrm{PO}}^{217.0458 \mathrm{~mm}}\right)$. The at $217.0005 \mathrm{~nm}: \mathrm{A}_{\mathrm{Pb}}^{217.0005 \mathrm{~nm}}=\mathrm{A}_{\text {total }}^{217.0005 \mathrm{~nm}}-\mathrm{A}_{\mathrm{PO}}^{217.0005 \mathrm{~nm}}=\mathrm{A}_{\text {total }} 217.0005 \mathrm{~nm}-\mathrm{k}\left(\mathrm{A}_{\mathrm{po}}^{217.0458 \mathrm{~nm}}\right)$. The
correction factor $k$ is calculated from slopes of calibration curves built up for phosphorous $(\mathrm{P})$ correction factor $k$ is calculated from slopes of calibration curves built up for phosphorous (P)
standard solutions measured at 217.0005 and $217.0458 \mathrm{~nm}$, i.e. $\mathrm{k}=\left(\mathrm{slope}^{217.0005} \mathrm{~nm} / \mathrm{slope}^{217.0458}\right.$ standard solutions measured at 217.0005 and $217.0458 \mathrm{~nm}$, i.e. $\mathrm{k}=\left(\right.$ slope $^{217.0005} \mathrm{~nm} / \mathrm{slope}^{217.04}$
$\mathrm{nm})$. For wavelength integrated absorbance of 3 pixels, sample aspiration rate of $5.0 \mathrm{ml} \mathrm{min} \mathrm{min}^{-1}$, $\left.{ }^{\mathrm{nm}}\right)$. For wavelength integrated absorbance of 3 pixels, sample aspiration rate of $5.0 \mathrm{ml} \mathrm{min}^{-1}$, sistently obtained. Calibration curves for P at 217.0005 and $217.0458 \mathrm{~nm}$ with linearity better than 0.998 were obtained. Relative standard deviations (RSD) of measurements $(n=12)$ in the range of $1.4-4.3 \%$ and $2.0-6.0 \%$ without and with mathematical equation correction approach were obtained respectively. The limit of detection $\mathrm{nm}$ was $10 \mu \mathrm{g} \mathrm{L}^{-1} \mathrm{~Pb}$. Recoveries for $\mathrm{Pb}$ spikes were in the $97.5-100 \%$ and $105-230 \%$ intervals with and without mathematical equation correction approach, respectively.

Keywords: mathematical equation correction approach; high-resolution continuum source flame atomic spectrometry; lead, phosphoric acid

\section{Introduction}

Among many factors affecting the determination of lead $(\mathrm{Pb})$ in phosphoric acid by flame atomic absorption spectrometry spectral and trans- port interferences are considered the more important ones [1], since the analytical line at 217.0005 $\mathrm{nm}$ ovelaps with $\mathrm{PO}$ molecur absortion bands 216.99 nm in PO molecular absorption bands at $216.99 \mathrm{~nm}$ in the air-acetylene flame [2], the alternate line at $283.3060 \mathrm{~nm}$ is recommended 
$[3,4]$. However both main and secondary lines for $\mathrm{Pb}$ are interfered if variations in phosphoric acid concentrations occur, changing the aspiration rate of the nebulizer.

Correction of spectroscopy interferences by mathematical equations in inductively coupled plasma mass spectrometry (ICP-MS) technique has already been established $[5,6]$. Nevertheless the adaptation of such mathematical equations to atomic absorption spectrometry for spectral interference correction was not feasible due to the lack of a truly simultaneous multi-element system. Recently and upon the introduction of a highresolution continuum source atomic absorption spectrometry (HR-CS AAS) [7], this problems been overcome as the whole [7], this probirom has been overoment around the ane Using this technique, the interference caused by $\mathrm{PO}$ molecules at the main line for $\mathrm{Pb}$ at 217.0005 $\mathrm{nm}$ may be eliminated using the least-squares background correction (LSBC) [1]. The alternate line at $283.3060 \mathrm{~nm}$ is unaffected by PO, but both main and secondary lines are interfered by transport effects. A method using the LSBC plus internal standardization was recently proposed to minimize these interferences in in the determinatio of $\mathrm{Pb}$ in phosphoric acid by HR-CS FAAS [1]

In this paper, a new approach to overcome spectral and transport interferences associated with the determination of $\mathrm{Pb}$ in phosphoric acid by HR-CS FAAS has been proposed. In principle, spectral overlap can be corrected providing that another wavelength of the interfering element is itself free from interference. The feasibility of using mathematical equation correction previously employed in ICP-MS, to eliminate spectral interference caused by $\mathrm{PO}$ molecules at the $217.0005 \mathrm{~mm}$ Pb line and tansport inter caused by variations in phosphoic acid concencaused by variations in phosphoric acid concentrations in the determination of $\mathrm{Pb}$ in phosphoric acid has been investigated.

\section{Instrumentation}

All measurements were carried out using an Analytik Jena ContrAA 300 high-resolution continuum source flame atomic absorption spectrometer equipped with a xenon short-arc lamp XBO 301 [10] with a nominal power of $300 \mathrm{~W}$ operating in a hot-spot mode as a continuum radiation source. This new equipment presents a compet high- This new equipton double-Echelle grating crating monochromator correspondent to a spectral ban width $<2 \mathrm{pm}$ per pixel in the far ultraviolet range tor.

High-purity (99.7\%) acetylene (Air Liquid, Brazil) was used as fuel gas. Air-acetylene oxidizing flame was used for analyte atomization. Solutions were directly aspirated by the burne nebulizer system of the spectrometer using an injection module (SFS 6) enabling the computerpiration of blanks, analytical solutions and samples.

Reagents, analytical solutions and samples

High purity de-ionized water (resistivity 18.2 $\mathrm{M} \Omega \mathrm{cm}$ ) obtained using a Millipore Rios $5^{\circ}$ reverse osmosis and a Millipore Milli-Q Acade$\mathrm{mic}^{\circledR}$ deionizer system (Bedford, MA, USA), and Merck Suprapur ${ }^{\circledR}$ nitric acid (Darmstadt, Germany) were used throughout to prepare all soluall solucal grade.

Reference solutions containing $0.10,0.20$ $0.40,0.80$ and $1.00 \mathrm{mg} \mathrm{L}^{-1} \mathrm{~Pb}$ were daily prepared by appropriate dilution of the $1000 \mathrm{mg} \mathrm{L}^{-1}$ single stock standard solutions (Normex ${ }^{\mathrm{TM}}$, Carlo Erba, Italy) and acidified to $1 \%(\mathrm{v} / \mathrm{v})$ with $\mathrm{HNO}_{3}$.

Working standard solutions containing 1.0, 2.5, 5.0 and $7.5 \%(\mathrm{~m} / \mathrm{v}) \mathrm{H}_{3} \mathrm{PO}_{4}$ were prepared by dissolving $1.18,2.48,5.88$ and $8.82 \mathrm{~g}$ of analytical reagent grade phosphoric acid 85\% (Mallinckrodt Xalostoc, Mexico) in 1\% (v/v) solution. Blank Xalostoc, Mexico) in 1\% (v/v) solution. Blank so$(\mathrm{v} / \mathrm{v})$.
Test solutions containing 100 or $400 \mu \mathrm{g} \mathrm{L}$ $\mathrm{Pb}$ in presence of $1.0,5.0$ and $7.5 \%(\mathrm{~m} / \mathrm{v}) \mathrm{H}_{3} \mathrm{PO}$ were used to illustrate the interference effects and the effectiveness of the proposed approach. These solutions were prepared by appropriate dilution of the $\mathrm{Pb}$ stock standard solution and concentrated phosphoric acid in $1 \%(\mathrm{v} / \mathrm{v}) \mathrm{HNO}_{3}$.

\section{Measurement procedure}

The measurement procedure is relatively simple. The absorbance for blank $[1 \%(\mathrm{v} / \mathrm{v})$ $\mathrm{HNO}_{3}$ ), reference standards $\left[0.10-1.00 \mathrm{mg} \mathrm{L}^{-1} \mathrm{~Pb}\right.$ in $1 \%(\mathrm{v} / \mathrm{v}) \mathrm{HNO}_{3}$ ] and phosphoric acid sample in $1 \%$ ( $/ \mathrm{V}) \mathrm{HNO}_{\mathrm{j}}$ ] $217.0005 \mathrm{~nm}$. The absorba of inter 217.0005 m. The absorbance of interfering species (PO) must be measured in the interfering an absorbances for all phosphoric acid working standard solutions $\left[1.0-7.5 \%(\mathrm{~m} / \mathrm{v}) \mathrm{H}_{3} \mathrm{PO}_{4}\right]$ were measured at $217.0005 \mathrm{~nm}$ and $217.0458 \mathrm{~nm}$. At $5.0 \mathrm{~mL} \mathrm{~min}{ }^{-1}$ of aspiration flow rate, fuel/oxidizing ratio $0.126,6 \mathrm{~mm}$ of burner height and wavelength-selected absorbance equivalent to $3 \mathrm{pi}$ xels, the equipment was adjusted under optimum conditions. All measurements were caried out in triplicates.

\section{Results and discussion}

Spectral and transport interferences on $\mathrm{Pb}$ : qualitative and quantitative data

Spectral interferences caused by phosphoric acid on $\mathrm{Pb}$ determination at the main line $217.0005 \mathrm{~nm}$ are due to the $\mathrm{PO}$ molecular absorption bands at $216.99 \mathrm{~nm}$ formed in the air-acety tion bands a 216.99 nm fored in the air-acetylene flame. This spectral interference was evaluated by calculating the apparent $\mathrm{Pb}$ concentration at the main line for $\mathrm{Pb}$ at $217.0005 \mathrm{~nm}$ for differen phosphoric acid solutions. When the acid concentration was varied from $0 \%$ to $7.5(\mathrm{~m} / \mathrm{v})$, the apparent $\mathrm{Pb}$ concentration varied from 0 to around $300 \mu \mathrm{g} \mathrm{L}^{-1}$, as well as the sample flow-rate reduced from 5.0 to $4.0 \mathrm{ml} \mathrm{min}^{-1}$. In earlier work, it was demonstrated that the LSBC technique is an efficient non-interfering wavelengths: in the present work,

tool to eliminate spectral interference caused by $\mathrm{PO}$ on $\mathrm{Pb}$ determination, but this correction technique did not avoid the transport effects caused by variations in phosphoric acid concentrations [1]

Determination of the correction factor for mathematical equation

If $\mathrm{PO}$ interfering molecule can be measure at a different wavelength free of any interference (and this is feasible in HR-CS FAAS), the correction factor can be calculated from the ratio of slopes of analytical curves for phosphoric acid built ing (217.0458 $\mathrm{nm}$ ) wavelenth and the absorbace at this last wavelength. The total absorbance $\left(\mathrm{A}_{\text {total }}\right)$ measured at $217.0005 \mathrm{~nm}$ corresponds

to the contribution of $\mathrm{Pb}$ plus $\mathrm{PO}$, so that:
$\mathrm{A}_{\text {total }}^{217.0005 \mathrm{~nm}}=\mathrm{A}_{\mathrm{Pb}}^{217.0005 \mathrm{~nm}}+\mathrm{A}_{\mathrm{PO}}^{217.0005 \mathrm{~nm}}$ Eq. (1)

To obtain the net absorbance for $\mathrm{Pb}$, the $\mathrm{PO}$ absorbance must be subtracted from the total absorbance at $217.0005 \mathrm{~nm}$

$\mathrm{A}_{\mathrm{pb}}^{217.0005 \mathrm{~nm}}=\mathrm{A}_{\text {total }}^{217.0005 \mathrm{~nm}}-\mathrm{A}_{\mathrm{pO}}^{217.0005 \mathrm{~nm}} \quad$ Eq. (2)

If absorbance of pure phosphoric acid standard solutions at the interfering $(217.0005 \mathrm{~nm})$ and non-interfering $(217.0458 \mathrm{~nm})$ wavelengths are measured, it is possible to estimate the $\mathrm{A}_{\mathrm{PO}}{ }^{217.000}$ ${ }^{\mathrm{nm}}$ by the application of Beer's Law [11] in both situations as bellow:

$\mathrm{A}_{\mathrm{PO}}{ }^{217.0005 \mathrm{~nm}}=\mathrm{A}_{\mathrm{PO}} 217.0458 \mathrm{~nm}$ (slope $217.0005 \mathrm{~nm} / \mathrm{slope}$ $217.0458 \mathrm{~nm})$ Eq. (3)

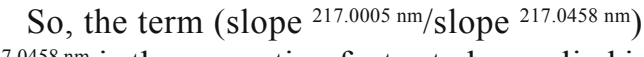
$\mathrm{A}_{\mathrm{pO}}{ }^{217.0458 \mathrm{~nm}}$ is the correction factor to be applied in Eq. (2) to obtain only the net absorbance for $\mathrm{Pb}$ : $\mathrm{A}_{\mathrm{pb}}{ }^{217.0005 \mathrm{~nm}}=\mathrm{A}_{\text {total }} 217.0005 \mathrm{~nm}$ - (slope ${ }^{217.0005 \mathrm{~nm} / \text { slope }}$

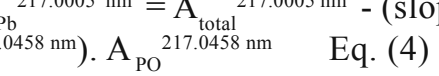

For wavelength integrated absorbance equivalent to 3 pixels, aspiration rate of the ne-

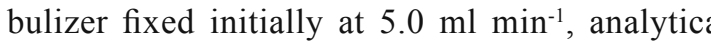
curves in the $0.1-1.0 \mathrm{mg} \mathrm{L}^{-1} \mathrm{~Pb}$ concentration range was always attained with linearity bette than 0.9990. Calibration curves for phosphoric acid (PO) at 217.0005 and $217.0458 \mathrm{~nm}$ presented plots within the $1.0-7.5 \% \mathrm{H}_{3} \mathrm{PO}_{4}$ with linear coefficient better than 0.9980 . Alternate wavelengths were tested for PO $216.9020 \mathrm{~nm}, 216.9940 \mathrm{~nm}$ the best linear coeffient for calibration curves. 
Additionally, it should be stressed that the line for PO at $217.0458 \mathrm{~nm}$ is within the spectral window for $\mathrm{Pb}$ at $217.0005 \mathrm{~nm}$ (Figure 1). The ratio between slopes of curves for PO (slope ${ }^{217.0005} \mathrm{~mm} / \mathrm{slope}^{217.0458 \mathrm{~mm}}$ was calculated daily taking into consideration that changes in the operating parameters alter the measured absorbance. However, ratios obtained in different days were usually within $1.23-1.29$, but were not significantly different at the $95 \%$ confidence level (paired $t$-test).

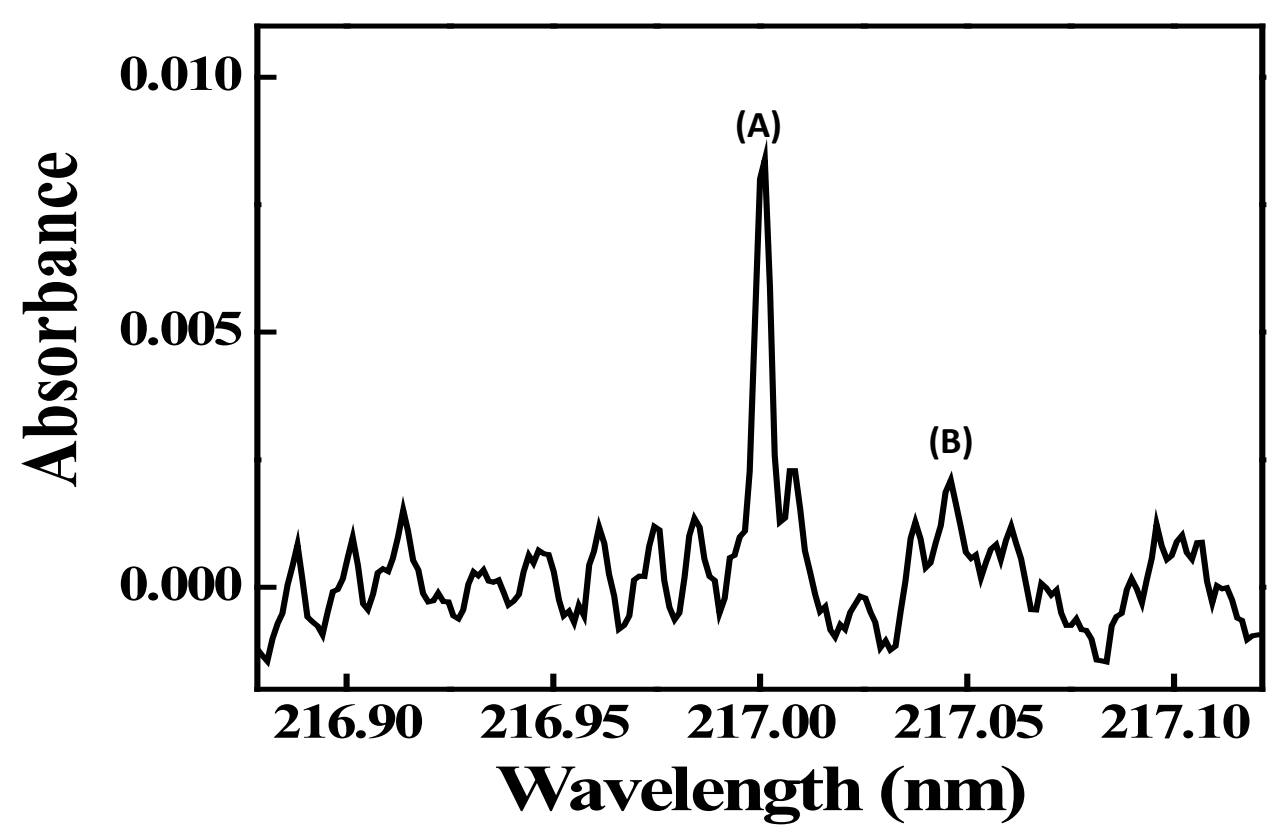

Figure 1. Spectrum recording for spiked $\mathrm{Pb}$ in phosphoric acid. (A) and (B) correspond to lines at 217.0005 $\mathrm{nm}$ and $217.0458 \mathrm{~nm}$, respectively.

\section{Analysis of test solutions and samples}

The feasibility of the mathematical correction for spectral and transport interferences was verified in the determination of $\mathrm{Pb}$ in test solutions and two phosphoric acid samples (Table 1). Results for samples were in agreement at a $95 \%$ confidence level (paired $t$-test) with those obtained by HR-CS FAAS using LSBC plus internal standardization. Precision and accuracy studies were also carried out using test solutions, or else, recovery experiments for diluted $[1 \%-7.5 \%$ $(\mathrm{m} / \mathrm{v})]$ phosphoric acid samples spiked with 100 and $400 \mu \mathrm{g} \mathrm{L}-1 \mathrm{~Pb}$.
If no correction method is applied, the concentrations of $\mathrm{Pb}$ found were in the $140-230$ $\mu \mathrm{g} \mathrm{L}^{-1}$ and $420-480 \mu \mathrm{g} \mathrm{L}^{-1}$ intervals for spiked samples with 100 and $400 \mu \mathrm{g} \mathrm{L}^{-1} \mathrm{~Pb}$, respectively. These results showed severe spectral interference caused by PO affected measurements at $217.0005 \mathrm{~nm}$ causing a positive interference much (1) caused by entert. On the other hand, when the mathematical equation approach was employed, the found concentrations of $\mathrm{Pb}$ were close to $\mathrm{Pb}$ gesting the usefulness of the proposal to eliminate spectral and transport interference. Relative standard deviations of measurements varied from 1.4 to $4.3 \%$ and 2.0 to $6.0 \%(n=12)$ without and spikes (recoveries in the $97.5-100 \%$ range), su-

with mathematical equation correction approach, respectively. The limit of detection calculated to analytical line at $217.0005 \mathrm{~nm}$ was $10 \mu \mathrm{g} \mathrm{L}-1 \mathrm{~Pb}$

Table 1 Comparative results for $\mathrm{Pb}(n=3)$ in commercial phosphoric acid samples and spiked $\mathrm{Pb}$ in test solutions (mean \pm standard deviation) determined by mathematical equation approach.

\begin{tabular}{ccc}
\hline \multirow{2}{*}{ Samples } & \multicolumn{2}{c}{$[\mathrm{Pb}], \mu \mathrm{g} \mathrm{L} \mathrm{L}^{-1}$} \\
Phosphoric acid & $94.4 \pm$ & \\
\cline { 2 - 3 } 1 & 3.5 & $51.2 \pm 2.9$ \\
& $91.2 \pm$ & \\
& 4.2 & $49.8 \pm 3.2$ \\
\hline Test solutio $\mathrm{n}$ & & \\
\hline & & $100 \pm 2$ \\
\hline $1.0 \%(\mathrm{~m} / \mathrm{v}) \mathrm{H}_{3} \mathrm{PO}_{4}+100 \mu \mathrm{g} \mathrm{L}^{-1}$ & $140 \pm 2$ & $100 \pm 5$ \\
\hline $5.0 \%(\mathrm{~m} / \mathrm{v}) \mathrm{H}_{3} \mathrm{PO}_{4}+100 \mu \mathrm{g} \mathrm{L}^{-1}$ & $200 \pm 7$ & $100 \pm 6$ \\
$7.5 \%(\mathrm{~m} / \mathrm{v}) \mathrm{H}_{3} \mathrm{PO}_{4}+100 \mu \mathrm{g} \mathrm{L}^{-1}$ & $230 \pm 9$ & $400 \pm 13$ \\
\hline $1.0 \%(\mathrm{~m} / \mathrm{v}) \mathrm{H}_{3} \mathrm{PO}_{4}+400 \mu \mathrm{g} \mathrm{L}^{-1}$ & $420 \pm 13$ & $390 \pm 19$ \\
$5.0 \%(\mathrm{~m} / \mathrm{v}) \mathrm{H}_{3} \mathrm{PO}_{4}+400 \mu \mathrm{g} \mathrm{L}^{-1}$ & $440 \pm 19$ & $390 \pm 19$ \\
\hline $7.5 \%(\mathrm{~m} / \mathrm{v}) \mathrm{H}_{3} \mathrm{PO}_{4}+400 \mu \mathrm{g} \mathrm{L}^{-1}$ & $480 \pm 18$ & \\
\hline
\end{tabular}

Conclusions

The accurate determination of $\mathrm{Pb}$ in high $\mathrm{P}$ content samples such as phosphoric acid by flame AAS requires an efficient method of interference correction. The alternate line for $\mathrm{Pb}$ at 283.3060 analyte deterTh $\mathrm{PO}$ interference, but it is interfered by transport effects. With the mathematical equation approach proposed, the main line for $\mathrm{Pb}$ at $217.0005 \mathrm{~nm}$ was efficiently employed for thi analytical task. The mathematical equation correction approach is obviously not limited to the analyte and sample selected in this work.

Additional studies with others elements and samples are necessary to corroborate the general application in flame AAS.

\section{Acknowledgements}

Authors would like to thank the Fundação de Amparo à Pesquisa do Estado de São Paulo for fnancially supporting this work and for the fellowship to S.R.O. The authors are also grateful to Coordenac̃o de Pessoal de Ensino Superior and Te Pessoal de En tífico e Tecnológico for fellowships to J.L.R.J., J.A.N., and researchship to J.A.G.N. 
Resumo: Um método de correção de interferência espectral e de transporte é proposto, e foi aplicado para minimizar interferências por moléculas de PO produzidas em chama ar-acetileno e de transporte causada pela variação da concentração de ácido fosfórico. Átomos de $\mathrm{Pb}$ moléculas de PO absorvem a $217,0005 \mathrm{~nm}$, então $\mathrm{A}^{217,0005 \mathrm{~nm}}=\mathrm{A}_{\mathrm{pp}}^{217,0005 \mathrm{~nm}}+\mathrm{A}_{\mathrm{po}}{ }^{217,0005 \mathrm{~nm}}$ Monitorando o comprimento de onda alternativo de PO em 217,0458 nm, é possível calcular a contribuição relativa de $\mathrm{PO}$ na absorbância total a $217,0005 \mathrm{~nm}: \mathrm{A}_{\mathrm{Pb}}^{217,0005 \mathrm{~nm}}=\mathrm{A}_{\text {total }}{ }^{217,0005 \mathrm{~nm}}$ - $\mathrm{A}$ ${ }^{217,0005 \mathrm{~nm}}=\mathrm{A}_{\text {to }} 217,0005 \mathrm{~nm}-\mathrm{k}\left(\mathrm{A}_{\mathrm{PO}}^{217,0458 \mathrm{~nm}}\right)$. O fator de correção $k$ é a razão entre os coeficientes angulares de duas curvas analíticas para $\mathrm{P}$ obtidas a 217,0005 e $217,0458 \mathrm{~nm}\left(\mathrm{k}=\mathrm{b}^{217,0005 \mathrm{~nm} /}\right.$

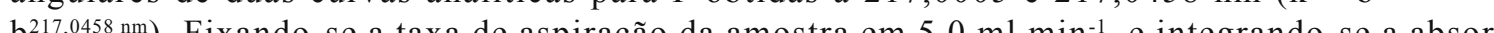
bincia bância no comping obtidas com coeficientes de correlação tipicos $\geq 0$, 9900 . As correlaçôes lineares entre absorbância e concentração de P nos comprimentos de onda 217,0005 e 217,0458 foram $\geq 0,998$. O limite de detecção de $\mathrm{Pb}$ foi $10 \mu \mathrm{g} \mathrm{L}{ }^{-1}$. O método de correção proposto forneceu desvios padrão relativos $(n=12)$ de 2,0 a 6,0\%, ligeiramente menores que os obtidos sem correção $(1,4-4,3 \%)$ As recuperações de $\mathrm{Pb}$ adicionado às amostras de ácido fosfórico variaram de 97,5 a 100\% (com correção pelo método proposto) e de 105 a 230\% (sem correção).

Palavras-chave: método de correção por equação matemática; espectrometria de absorção atômica com fonte contínua e de alta resolução; chumbo; ácido fosfórico.

\section{References}

[1] J.L. Raposo Jr, S.R. Oliveira, J.A. Nóbrega, J.A. Gomes Neto, Spectrochim. Acta Part B 63 (2008) 992.

[2] PLASUS Ingenieurbüro, Plasus Specline, Version 2.13, Konnigsbrun, Germany, 2005.

ns, W. Slavin, Spectrochim. Acta, Part B 49 (1994) 1667

[4] J.B. Willis, B.T. Sturman, J. Anal. At. Spectrom. 19 (2004) 706.

[5] S. M. Nelms, Inductively Coupled Plasma Mass Spectrometry Handbook, first ed., Wiley-Blackwell, 200

[6] F. Laborda, M. P. Górriz, E. Bolea, J. R. Castillo, Spectro[7] B. Wetz, H. Beck (2006) 433 .

[7] B. Welz, H. Becker-Ross, S. Florek, U. Heitmann, HighResolution Contion Source AAS: The Better Way to Do

[8] B. Welz, Anal. Bioanal. Chem. 381 (2005) 69

[] B. Welz, H. Becker-Ross, S. Florek, U. Heitmann, M.G.R. Vale, J. Braz. Chem. Soc. 14 (2003) 220

[10] M.D. Huang, H. Becker-Ross, S. Florek, U. Heitmann,

M. Okruss, J. Anal. At. Spectrom. 21 (2006) 338.

[1] D. H. Hois, Q

ny, New York, 2007.

\section{PHOTO-FENTON PROCESS FOR TREATING BIOLOGICAL LABORATORY WASTEWATER CONTAINING FORMALDEHYDE}

Janaina Conrado L. Fonseca ${ }^{a}$, Raquel F. Pupo Nogueira ${ }^{b}$, Mary Rosa Rodrigues Marchi ${ }^{b^{4}}$

a UNESP Waste Management Program, UNESP - Univ Estadual Paulista Rectory Office, 01049-010, São Paulo - SP, Brazi

${ }^{b}$ Institute of Chemistry, UNESP - Univ Estadual Paulista, P.O.Box 355, 14800-900, Araraquara - SP, Brazil.
*Corresponding author: Phone: +55-16-3301-6610. Fax: +55-16-3301 6692; e-mail address: mssqam @iq.unesp.br

Abstract: Laboratories consume great amounts of hazardous chemicals substances and consequently generate wastewater containing them, for example formaldehyde. This substance is widely utilized to preserve biological samples generating many liters of this residue every year. The present work proposes the use of the photo-Fenton process to treat formaldehyde wastewater using sunlight irradiation. Some aspects were investigated such as the iron source, sample and hydrogen peroxide concentration and also the use of stirred systems. The use of ferrioxalate $(0.5 \mathrm{mmol} \mathrm{L}-1)$ improved the efficiency of the process in relation to the use of iron nitrate, while at least $1.0 \mathrm{~mol} \mathrm{~L}-1 \mathrm{H} 2 \mathrm{O} 2$ is necessary to treat the sample of the $500 \mathrm{mg} \mathrm{C}$ L-1. Under these conditions, every formaldehyde detectable was degradeted and $89 \%$ of the dissolved organic carbon was removed in two hours of exposure to sunlight. These results are satisfaction considerate for São Paulo State Environmental Agency.

Keywords: laboratory wastewater treatment, formaldehyde, photo-Fenton

\section{Introduction}

A large number of biological laboratories use solutions of formaldehyde to preserve anatomic pieces, generating many liters of formaldehymic pieces, generating many liters of formaldehyde waste every year. In according to the literature
formaldehyde is genotoxic in exposed cells in viformaldehyde is genotoxic in exposed
tro or exposed tissues in vivo $[1,2,3]$

tro or exposed tissues in vivo $[1,2,3]$ de is just $3.7 \% \mathrm{w} / \mathrm{w}$, discharging formaldehyde without treatment can cause serious damage from aquatic environment, due to its carcinogenicity [4] and there is no safe limit to exposition for this class (carcinogenic). Hence, these wastes require an appropriate treatment to avoid risks to the environment and human health.
The adequate treatment of wastes generated by industrial, agricultural or domestic activities is regulated by environmental agencies throughout the world, $[5,6]$ which the levels of specific parameters are limited and checked in the dischaged wastes. This is necesary due to lange vol ged wastes. This is necessary due to lange volumes of toxic generated wastes and consequently to the impacts that this cause. The formaldehyde, for example, is able to react with DNA, RNA and proteins, damaging cells and causing the death of microorganisms present in biological wastewater treatment plants $[7,8]$.

Furthermore, the residues generated by Universities and Research Centers offers a special challenge: present specific treatments of differen wastes. The ideal solution would be an in situ waste The ideal solution would be an in si 